This work is licensed under a Creative Commons Attribution 4.0 International License.

Ovaj rad dostupan je za upotrebu pod licencom Creative Commons Imenovanje 4.0 međunarodna.

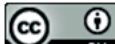

Krešimir ŠıMIĆ

UUDK 80:1

Filozofski fakultet

80:027

Sveučilišta J. J. Strossmayera u Osijeku

Lorenza Jägera 9

HR - 31000 Osijek

ksimic@ffos.hr

Izvorni znanstveni članak

Original Research Article

Primljeno 9. rujna 2020.

Received: 9 September 2020

Prihvaćeno 20. prosinca 2020.

Accepted: 20 December 2020

\title{
BILJEŠKA O FILOLOGIJI
}

\section{Sažetak}

U članku se prvo analizira polemika između Ulricha von Wilamowitz-Möllendorffa i Friedricha Nietzschea nastala povodom objavljivanja Nietzscheove prve knjige Die Geburt der Tragödie aus dem Geiste der Musik (1872), a zatim i polemika između Waltera Jacksona Batea i Paula de Mana povodom objavljivanja Bateova članka The Crisis in English Studies. Iz spomenutih polemika nastoji se ocrtati osnovne smjernice u devetnaestostoljetnom i dvadesetostoljetnom razumijevanju filologije. Konačno, donosi se vlastito viđenje filologije iz vizure kršćanske tradicije, odnosno

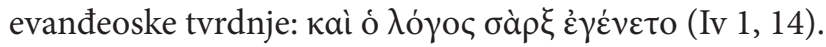

Ključne riječi: filologija, tijelo, vjera, Ulric von Wilamowitz-Möllendorffa, Friedrich Nietzsche, Walter Jackson Bate, Paul de Man 
I.

U jesen 1987. ravnateljica Centra za književne i kulturalne studije na Sveučilištu Harvard (Center for Literary and Cultural Studies at Harvard University) Marjorie Garber sazvala je sastanak na kojemu su članovi izvršnog odbora bili zamoljeni da predlože teme za nadolazeću konferenciju. Garberin kolega s Harvarda, klasični filolog latinist i medijevalist, Jan Ziolkowski predložio je temu „Što je filologija?“. Pritom je mislio na sljedeće smjernice: najranija i kasnije uporabe riječi filologija u različitim studijima, odnos između filologije i lingvistike, razlika između filologije i egzegeze u studiju „svetih tekstova“ te mjesto filologije u književnoj teoriji. Predložena tema članovima izvršnog odbora, mahom profesorima koji se bave suvremenim književnostima, činila se perifernom. Razlozi koje je naveo (interes klasičnih filologa i medijevalista te „podsvjesno življenje“ s filologijom gotovo svih stručnjaka za jezike i književnost), ističe Ziolkowski, nisu pobudili interes. Interes za naznačenu temu abruptno se pojavio kada je Ziolkowski spomenuo članak Paula de Mana The Return to Philology (The Times Literary Supllement, 10. Dec. 1982., 1355-1356; kasnije tiskano u: The Resistance to Theory). Konačni poticaj za prihvaćanje predložene teme bilo je podsjećanje da je suvremena polemika o odnosu filologije i književne teorije - koju je pokrenuo de Manov članak - anticipirana devetnaestostoljetnim srazom Ulricha von Wilamowitz-Möllendorffa i Friedricha Nietzschea (Ziolkowski 2-4). Točnije: sâm Nietzsche nije odgovorio na Wilamowitzevu oštru kritiku (Zukunftsphilologie!) njegova prvijenca Die Geburt der Tragödie aus dem Geiste der Musik (1872), već su to učinili njegovi tada bliski prijatelji - Richard Wagner okružnim pismom (Zirkularbrief, u: Norddesutscher Allgemeine Zeitung, 23. lipnja 1872.) i Erwin Rohde spisom Afterphilologie: Zur Beleuchtung des von dem Dr. phil. Ulrich von Wilamowitz-Möllendorff herausgegebenen Pamphlets: „Zukunftsphilologie!“ Sendschreiben eines Philologen an R. Wagner (1872), na što je Wilamovitz odgovorio spisom Zukunftsphilologie! Zweites Stueck. Eine Erwiderung auf die Rettungsversuche für Nietzsches Geburt der Tragödie (1873). ${ }^{1}$

Konferencija je održana 1988. godine. Prilozi su tiskani u posebnom broju časopisa Comparative Literature Studies (XXVII, 1, 1990) naslovljenom What is Philology?, a zatim i kao knjiga On Philology (1990), koju je uredio Ziolkowski.

\footnotetext{
${ }^{1}$ Na početku Wilamowitzeva drugog spisa kao godina izdanja navodi se 1873., iako na kraju (24. stranica) piše: „Rome, 22. Dez. 1872.“ (Groth 179). Svi gorespomenuti tekstovi nalaze se u: Der Streit um Nietzsches „Geburt der Tragödie“: die Schriften von E. Rohde, R. Wagner, U. v. Vilamowitz-Möllendorff, ur. K. Gründer, Georg Olms, 1969.
} 
Većina priloga nije bila koncentrirana na pokušaj definiranja filologije, već na njezino mjesto u hijerarhiji studija književnosti. Sâm Ziolkowski zagovarao je svojevrsno pomirenje između filologije i teorije književnosti, ali se ujedno pitao: „Postoji li srednje tlo između dekonstruktivnih ciljeva nekih teorija i rekonstruktivnog projekta filologije?" (What is Philology 11). Konferencija je potaknula i daljnje debate, naročito u medijevalnim studijama. Gotovo istodobno debatu među medijevalistima u frankofonom svijetu potaknula je knjiga Bernarda Cerquiglinia Éloge de la variante. Histoire critique de la philologie (1989), napisana pod utjecajem Michela Foucaulta i Jacquesa Derridae. Iz debata se izrodio projekt nazvan nova filologija (New Philology), koji se - valjda ne slučajno jer je također riječ o svojevrsnom isprepletanju filologije i teorije - pojavio paralelno s novim historizmom (New Historicism). Orijentacijska zbirka članaka za potonji projekt je The New Historicism (1989), dok je za novu filologiju poseban broj časopisa Speculum $(1,1990)$ naslovljen The New Philology. Oba su projekta vezana za dublje slojeve književne povijesti: novi historizam uz renesansne studije, nova filologija uz medijevalne studije (stoga se uz novu filologiju često veže i novi medijevalizam - New Medievalism). ${ }^{2}$

Projekt nova filologija (koji, kao i novi historizam, niječe da je riječ o formalnoj teoriji ili metodologiji, već radije o jednom općem pristupu) pod utjecajem postmodernih teorija iz 70 -ih i 80 -ih godina ističe da se smisao filologije ne iscrpljuje samo u studiju riječi (Wortphilologie) i jezika nego i u studiju kulture. U fokusu su, dakle, medijevalni rukopisi, ali s naglaskom na sve elemente rukopisa: rukopisne oznake, ilustracije, marginalije, povijesnu transmisiju, piščev i čitateljev tretman (Yager 999). Jedan od poznatijih promotora nove filologije Stephen Nichols u uvodniku New Philology novi projekt opisuje kao „postmoderni povratak izvoru medijevalnih studija“ usuprot anakronoj koncepciji filologije „formulirane pod utjecajem političkog nacionalizma i znanstvenog pozitivizma tijekom druge polovice devetnaestoga stoljeća“ (1 i 7).

Kako se naglo pojavila, tako, čini se, nova filologija naglo gubi na popularnosti - i to, tvrdi Gabrielle Speigel, zbog gubitka popularnosti postmodernih teorija koje su ju iznjedrile. Štoviše, Speigel u osvrtu na posebni broja Speculuma iz 1990. godine tvrdi da je ono što se nazivalo ,jezični okret“ (postmodernizam

\footnotetext{
${ }^{2}$ Nova filologija nije prihvaćena sveopćim oduševljenjem, čak ni u sjevernoameričkom akademskom milieu. Snažnije kritike pojavile su se među francuskim i njemačkim medijevalistima. Najčešći prigovori odnosili su se na uredničke procedure, i to ne samo pri objavljivanju srednjovjekovnih tekstova (Ziolkowski, Metaphilology 243-46).
} 
i poststrukturalizam) doživjelo svoj završetak (48). Je li „jezični okret“ doživio svoj završetak, ne znam; ali da su polemika Nietzsche - Wilamowitz - Wagner - Rohde (ako je o polemici uopće riječ, jer napadnuti autor ne odgovara) i de Manov spomenuti članak, pri čemu je također riječ o svojevrsnoj polemici jer je de Man svoj članak napisao kao reakciju na članak Waltera Jacksona Batea The Crisis in English Studies, i nadalje poticajni za iznalaženje relevantnih humanističkih tema i smjerodavni za njihovo promišljanje, držim da je nedvojbeno. Stoga ću nadalje razmotriti devetnaestostoljetnu (Nietzche - Wilamowitz - Wagner - Rohde) i dvadesetostoljetnu (Bate - de Man) „polemiku“ da bih naznačio ishodišne točke prijepora te, konačno, naznačiti jedno drugačije viđenje zasnovano na kršćanskoj egzegetskoj i biblijsko-teološkoj tradiciji.

\section{II.}

Kada se tijekom devetnaestoga stoljeća filologija etablirala kao akademska disciplina, usredotočena na klasičnu grčku i latinsku književnu kulturu (Altertumswissenschaft), Nietzsche je zagovarao jednu novu filologiju. U eseju „Wir Philologen“ ustvrdio je: „Man glaubt es sei zu Ende mit der Philologie - und ich glaube, sie hat noch nicht angefangen [... ]“ (KSA 8, 34). ${ }^{3} \mathrm{Na}$ kakvu je filologiju koja još nije ni započela mislio, naznačio je već u svojim baselskim predavanjima. Nietzsche je bliskom prijatelju Erwinu Rohdeu povjerio da je tijekom svojega prvog semestra u Baselu (u proljeće 1869. godine) „inficirao“ studente filozofijom. U pismu od 7. lipnja 1871. ustvrdio je, povodom predavanja Einleitung und Encyclopädie, da se studenti, na vlastito zaprepaštenje, jedva mogu prepoznati u slici idealnog filologa koju je skicirao (KSB 3, 197). Nadalje, govorio je studentima da ukoliko žele biti klasični filolozi, prvo moraju biti „moderni“; da ukoliko žele „kultivirati anakronizam“, moraju upoznati „velike mislitelje“ moderne kulture (Winckelmann, Lessing, Schiller, Goethe i Kant). Naznačenu filologiju nazvao je „filologijom budućnosti“ (Philologie der Zukunft) (Porter $30-31){ }^{4}$

\footnotetext{
${ }^{3} \mathrm{KSA}=$ Kritische Studienausgabe. Sämtliche Werke, ur. von G. Colli i M. Montinari, Walter de Gruyter; $\mathrm{KSB}=$ Kritische Studienausgabe. Sämtiche Briefe, ur. von G. Colli i M. Montinari,Walter de Gruyter; FS = Frühe Schriften, ur. von C. Koch i K. Schlechta, Beck.

${ }^{4}$ Iako se prema često citiranoj misli iz Wir Philologen („Gegen die Wissenschaft der Philologie wäre nichts zu sagen: aber die Philologen sind auch die Erzieher“, KSA 8, 14) u prvi mah može činiti da Nietzsche o tadašnjoj filologiji ne misli nužno loše, odnosno da je njegov stav u najmanju ruku ambivalentan (Benne 23), riječ je o klasičnoj hijastičkoj shemi kojom je Nietzsche htio izazvati uobičajeno mišljenje o odgojnoj ulozi povijesno-kritičke filologije (Babich, „Nietzsche’s Philology“ 155).
} 
Za odlučujući trenutak rušenja „stare“ filologije drži se Nietzscheova prva knjiga, o „rođenju“ grčke tragedije: Die Geburt der Tragödie aus dem Geiste der Musik (1872). Osnovna teza knjige - da se grčka tragedija „rađa“ iz dvaju nagona: dionizijskog (vrijuće životne bujice, što se javlja kao zastrašujuća jeza i blažena začaranost koja nastupa dokidanjem razuma i erupcijom iracionalnog, snaga razaranja individuacije koja vodi u utrobu bitka, u najdublju jezgru stvari, u Pra-Jedno) i apolonskog (pričin koji se rađa iz poriva da se ono jezovito, vrijuće, sakrije; preobrazujuća snaga principa individuacije), iz protuigre Doniza i Apolona shvaćene kao supripadno jedinstvo - nije bila toliki novum (von Reibnitz 29, 183), koliko tvrdnja da se upravo u grčkoj tragediji pokazuju te osnovne moći bitka koje jedna drugu dokidaju. Riječ je, dakle, o tumačenju svijeta umjetnošću, o metafizici umjetnosti, o tragičkom viđenju svijeta do kojega se dolazi intuicijom (Anschauung), munjolikim uvidom u bît stvari, o „estetskoj znanosti“ (ästhetischen Wissenschaft) koja se ne zasniva na apstraktnim znanstvenim pojmovima već na iskustvu, intuiciji, neposrednom uvidu. Usuprot novoj znanosti nalazi se, tvrdi Nietzsche, sokratizam (ono „logičko“, koje nema oko za ono što buja, za „život“), ,aleksandrijska kultura“ u kojoj prebiva vječno gladan „kritičar“, bez volje i snage, knjižničar i korektor oslijepio od knjiške prašine i tiskarskih pogrješaka; kultura koja je započela pojavom Sokrata, Euripida (kod kojega je logički nagon nadvladao nagon za mitskim) i novijih ditirampskih pjesnika (koji su glazbu učinili imitatorskom slikom pojave i tako je lišili mitotvorne moći).

Kada se Wilamowitz - Nietzscheov kolega iz gimnazijskih i studentskih dana (isprva su obojica polazili slavnu Schulpforta Gymnasium, a zatim studij klasične filologije u Bonnu) - ubrzo nakon tiskanja Nietzscheove knjige o tragediji odlučio za njezinu kritiku, našao se pred dvojbom: kakvim se stilom treba poslužiti u polemici protiv knjige koja se ne pridržava konvencija klasičnih studija. Naime, uz vitalističke jezične geste (vjenčanje, spolno zajedništvo, rađanje, potomstvo), u Die Geburt der Tragödie riječ je o mješavini promišljanja o grčkoj mitologiji, muzikologiji i Schopenhauerovoj filozofiji napisanim bez bilježaka, bez citiranja grčkih izvora, bez referiranja na klasični studij, čak bez naracije karakteristične za klasične i moderne udžbenike (Porter 73). ${ }^{5}$ Klasični filolo-

\footnotetext{
${ }^{5}$ Osim Wilamowitza (1872) i (1873), prvo izdanje Die Geburt der Tragödie (1872) stručnjaci nisu recenzirali (o mišljenju klasičnih filologa F. Lea, O. Ribbecka, F. Ritschla, H. Usenera i J. Bernaysa usp. Calder 214-254). Recenziju drugog izdanja (1874) napisao je H. Guhrauer (u: Jahrbücher für Philologie und Pädagogik, 1876, 109: 49-63). U anglosaksonskom području, točnije krugu Cambridge School, Nietzschea je predstavila J. Harrison (usp. dvije njezine knjige: Prolegomena to the Study of
} 
zi svoje su tvrdnje potkrjepljivali bilješkama kojim su se referirali ili izravno na drevne tekstove ili neizravno na druge filologe (Fußnotenphilologie). ${ }^{6} \mathrm{Wi}$ lamowitz je stoga odustao od početne nakane da napiše prikaz Die Geburt der Tragödie i odlučio se za svojevrsni pamflet (Broschüre), odnosno - kako je sâm Wilamowitz ustvrdio u pismu od 3. travnja rektoru Schulpforte Carlu Ludwigu Peteru - „meine Invective“ (Calder 227). Ubrzo je shvatio da „invektivu“ neće objaviti nijedan respektabilan znanstveni časopis, pa ju je sâm financirao i objavio u svibnju 1872. godine, dakle svega tri mjeseca nakon objavljivanja Nietzscheove knjige (227). Iako se odlučio za formu pamfleta, oba Wilamowitzeva teksta (1872. i 1873.) opremljena su uobičajenom znanstvenom aparaturom: bilješkama u kojima se referira na izvorne tekstove i druge znanstvene izvore ( $\mathrm{u}$ prvom pamfletu u prosjeku na svakoj od 27 stranica dolaze dvije bilješke, koje su prave minijaturne znanstvene rasprave, dok je u drugom pamfletu, koji je nešto kraći, manje bilježaka). To je, dakle, bilo njegovo „oružje“ (Meine Waffen) protiv Nietzschea (Wilamowitz, Zukunftsphilologie! 32; usp. Porter 76-77). ${ }^{7} \mathrm{Za}$ nimljivo, Wilamowitzevo oružje protiv Nietzschea bilo je i krajnje nefilološko: intencionalno i sistematsko krivo citiranje sâmog Nietzschea. ${ }^{8}$ Očito: s jedne strane pokazao je koliko cijeni znanstvenu aparaturu (citiranje izvora i referiranje na znanstvene radove), a, s druge strane, koliko malo cijeni Nietzscheov tekst. $^{9}$

Nakon što je na sâmom početku svojeg prvog pamfleta, na gotovo stranici i pol, citirao ulomak Nietzscheove knjige (Zukunftsphilologie! 5-6), Wilamowitz je napomenuo da je to učinio da bi ukazao na "ton und tendenz des buches“ (Zukunftsphilologie! 6). Nietzscheov "ton und tendenz“, smatra Wilamowitz,

Greek Religion, 1903. i A Study of the Social Origins of Greek Religion, 1912.). Članak H. Lloyd-Jonesa Nietzsche and the Study of the Ancient World (u: Studies in Nietzsche and the Classical Tradition. ur. J. C. O’Flaherty, T. F. Sellner i R. M. Helm, U of North Carolina P, 1979, str. 1-15) dao je pak snažan poticaj za novija istraživanje Nietzscheova doprinosa klasičnoj filologiji (von Reibnitz 1).

${ }^{6}$ Drugi je, češći naziv, ali s ironijskim prizvukom: Anmerkungwissenschaft. O važnosti bilježaka, posebice za klasičnu filologiji, vidjeti: Grafton 1997.

${ }^{7}$ Wilamowitz ističe da je Nietzscheovo oružje „samovoljno izokretanje“ („seine waffen aber sind geflissentliche entstellungen“ (Zukunftsphilologie! 25).

${ }^{8}$ Wilamowitz čak u prvoj bilješci ističe „Die zahlen im text geben die seiten des Nietzscheschen Buches".

${ }^{9}$ Pomnu analizu netočnih Wilamowitzevih navoda iz Die Geburt der Tragödie u oba Wilamowitzeva pamfleta sačinio je J. Poter (73-99). On je također naveo i Wilamowitzeva pogrješna citiranja Rohdeova teksta Afterphilologie. Već se sâm Nietzsche potužio E. Rohdeu da ga Wilamowitz pogrješno citira, pa čak i da preinačuje njegov tekst (78-79). 
nipošto ne ukazuju na znanstvenog istraživača, već na epopta (inicijanta u misterije), propovjednika, novinara (Zukunftsphilologie! 6). Optužio je Nietzschea da ga je Wagner uvjerio u vlastite koncepcije (apolonijski san i dionizijska opijenost) te da je otuda prihvatio i Schopenhauerovu ideju o prvenstvu glazbe nad ostalim umjetničkim izražajima. Nadalje, ukazao je na Nietzscheove faktografske pogrješke (tvrdio je da Nietzsche uopće nije čitao Winckelmanna, kojega spominje zajedno s Goetheom i Schillerom) (Zukunftsphilologie! 8-9), na Nietzscheovo nepoznavanje Homera (Wilamowitz se pitao kako je Nietzsche mogao Homeru pripisati pesimističku sentimentalnost, staračku čežnju za ništavilom, svjesno samozavaravanje. Također je tvrdio da je Nietzsche Homera poznavao samo iz Natjecanja Homera i Hezioda, gdje je Homer prikazan kao „slijepi prosjak“). Zatim je ustvrdio: „Welche schande hr. N [ietzsche] machen Sie der mutter Pforte!“ (Zukunftsphilologie! 12). Wilamowitz je spomenuo i brojne druge Nietzscheove filološke pogrješke i povijesno netočne tvrdnje o Arhilohu, Eshilu, Euripidu, Sokratu da bi zaključio kako sve ono što je Nietzsche tvrdio o tragediji može biti rečeno i za komediju te da je Nietzsche bio neznalica u pitanjima Grka i običan šarlatan (Zukunftsphilologie! 24). Konačno, Wilamowitz je ustvrdio da će povući svoj polemički spis (jer filološka metoda njegove polemike ne može naškoditi Nietzscheovoj knjizi) ako Nietzsche odgovori da nije bio zainteresiran za filološko-historiografske činjenice, već da mu je jedini cilj bio napisati dionizijsko-apolonijsko umjetničko djelo, „metafizički lijek“" (metaphysisches trostmittel) i da njegove tvrdnje pripadaju „višem realizmu svijeta sna“ (höhere realität der traumwelt). Ali - Wilamowitz ujedno moli Nietzschea (referirajući se na završetak dvadesetog poglavlja Die Geburt der Tragödie) neka tada zgrabi tirsos, otputuje od Indije u Grčku, neka siđe sa svoje katedre profesora klasične filologije na kojoj je pozvan poučavati Wissenschaft (Zukunftsphilologie! 32).

Na Wilamowitzev pamflet ubrzo je reagirao Wagner, koji je u svojoj okružnici ustvrdio da je Rođenje tragedije bio „proplamsaj genija“ i da nema potreba za opravdavanjem pred tako niskom stvari kao što je učenjaštvo (Bilić 16). U svom obimnom odgovoru - koji je objavio kao anoniman tekst - Rohde je također podržao Nietzscheove postavke i intuicije (naročito povezanost sna i umjetnosti). Prema Rohdeu, čak i filologija kao čista povijesna znanost (Wissenschaft) treba nadahnuće filozofije pri oblikovanju ideja o starini. Uvjerenje u objektivnost (dohvaćanje bîti antičke umjetnosti) koja se zasniva samo na „svjedočanstvima“ (Zeugnisse), iluzorno je (73-74; usp. Porter 87). Stoga je filologija zasnovana 
na pukom pozivanju na izvornu i sekundarnu građu zapravo „postfilologija“ (Afterphilologie). Iako je, za razliku od Nietzschea, Rohde svoj tekst napisao u modusu Fußnotenphilologie (opremljen citatima i referiranjem na znanstveni filološki studij), optužio je Wilamowitza da se obrušio na Nietzschea vrstom erudicije koja se može pronaći u bilo kojem priručniku, odnosno pokušajem da se vlastiti stav potvrdi mnoštvom citata. Wilamowitz je u svom drugom pamfletu (1873) - odgovoru Rohdeu ${ }^{10}$ - napisao da je bolestan od prepirke i da nakon svega nije zainteresiran za ispravljanje filoloških pogrješki njegovih oponenata te je zaključio:

$\mathrm{Ne}$, ovdje je jaz koji nikada ne može biti premošten. Za mene je najviša ideja zakonit, živ i razuman razvoj svijeta. Zahvalno gledam prema velikim umovima koji su korak po korak otkrivali tajne svijeta. Ovdje (kod Nietzschea - op. K. Š) vidim nijekanje razvoja vjekova. Otkrića filozofije i religije ugašeni su da bi isprani pesimizam mogao pokazati svoje gorko-slatko lice u pustošenju. Božanske slike kojima su pjesništvo i umjetnost nastanili naša nebesa razmrvljene su da bi se idol Richard Wagner mogao štovati nasred razvalina. Čitava građevina podignuta neizrecivim radom i briljantnom genijalnošću do temelja se uništava da bi opijeni sanjar mogao upraviti prodoran pogled $\mathrm{u}$ dionizijske ambise: To je bilo više negoli sam mogao podnijeti. (23-24; usp. Groth 186-87)

Jasno je - Wilamowitz je nastojao obraniti filologiju kao Wissenschaft usuprot Nietszcheovoj filologiji shvaćenoj kao „hijerofantička mistična mudrost“ (hierophanten mystische weisheit) (Zukunftsphilologie! 20). U svojem posljednjem, nedovršenom djelu, Der Glaube der Hellen, Wilamowitz je ponovno ustvrdio: „Kao što opijenost ima malo toga sa začećem tragedije, tako malo toga ima Apolon, osvajač inkubacije, sa snom; usuprot, Die Geburt der Tragödie je sanjana" (nav. prema: Groth 188). ${ }^{11} \mathrm{U}$ svojim je pak memoarima, nakon što je

${ }^{10}$ Iako E. Rohde u Afterphilologie nigdje ne navodi svoje inicijale ili na drugi način otkriva svoj identitet, Wilamowitz na početku svog drugog pamfleta napominje da ih je Rohde naveo - što je još jedan primjer, čini se, Wilamowitzeve intencionalne pogrješke (Porter 98, bilj. 45).

${ }^{11} \mathrm{~J}$. H. Groth napominje da su se vodeći filolozi uglavnom složili s Wilamowitzevom osudom i da je sljedeći semestar u Baselu Nietzsche imao samo dva studenta. Međutim, nepotrebno je spominjati da je Nietzsche kasnije stekao prevagu. Samo, tâ prevaga, napominje Groth, izuzetno je opasna (od Nietzscheova djela o tragediji, zatim djela H. S. Chamberlaina, O. Spenglera, E. Friedella, A. Rosenberga do Hitlerova Mein Kampfa samo je korak - tvrdi Grothe) jer se zasniva na načelu „dogma korigira povijest“, romantičarskom konceptu genija, divinacije, intuicije. Usuprot takvoj tendenciji

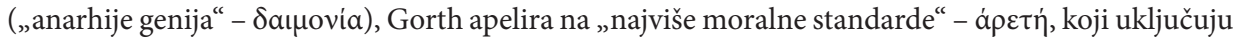
zajednicu. Znanost pretpostavlja zajednicu, a ne demonski nadahnute pojedince (188-89). Grotho- 
ustvrdio da je bio budalast momak i krajnje slijep za pretencioznost svojih pamfleta, napisao: „Nemam razloga za žaljenje: slijedio sam svog deamona [...] sve zbog moje znanosti, koja je, vjerujem, bila u opasnosti“ (Wilamowitz Erinnerungen 130; nav. prema Porter 90).

Nietzsche je dakle, i to ne samo svojom knjigom o grčkoj tragediji već svojim cjelokupnim opusom, ponudio razmišljanja koja nisu bila samo razmišljanja o filologiji već o znanosti općenito. Usuprot sokratizmu, odnosno teorijskom čovjeku koji je službenik znanosti zasnovane na bîti logičkog, ukazao je na fenomen dionizijske umjetnosti koja očituje volju u svoj njezinoj moći, život onkraj pojavnosti i individuacije. Stoga je, isticao je Nietzsche, istinska znanost umjetnost. Pritom se ističe glazba, koja se od ostalih umjetnosti razlikuje po tome što nije slika pojave, već izravna slika sâme volje, mimo svijesti. Ona pobuđuje na „metaforički zor“ dionizijske općenitosti (Nietzsche, Rođenje tragedije 111). Jezik pak kao organ pjevâ ne može najdublju nutrinu glazbe okrenuti prema van, nego uvijek ostaje samo u vanjskom dodiru s glazbom. Liričar stoga ne može izreći ništa što već u neizmjernoj općenitosti, u praproturječju Pra-Jednog (Ur-Eine), nije bilo sadržano u glazbi koja ga je primorala na slikovni govor (ibid.). O Nietzscheovu shvaćanju jezika bit će ponešto riječi nakon prikaza druge, dvadesetostoljetne „polemike“: Bate - de Man.

III.

De Man je svoj članak The Return to Philology, spomenuo sam, napisao kao reakciju na Bateov članak The Crisis in English Studies. Harvardski profesor Bate odmah je na početku svojega članka ustvrdio da su se humanističke znanosti (humanities) našle u najdubljoj krizi otkad su zasnovana moderna sveučilišta (1880-ih godina). Dotada je, ističe Bate (The Crisis 46), većina zapadnih sveučilišta slijedila medijevalni i renesansni kurikul - u kojemu je, unatoč nekim nedostatcima, postojalo jedinstvo znanja i brige za obrazovanjem. Od druge polovice devetnaestoga stoljeća, nastavlja Bate ocrtavati dijagnozu suvremene humanistike, specijalizacija koja se počela događati na njemačkim sveučilištima

vu tvrdnju da su se vodeći filolozi uglavnom složili s Wilamowitzevom osudom treba uzeti s rezervom. Naime, Wilamowitzevi studenti Paul Friedländer, Karl Reinhardt, Werner Jaeger, Wolfgang Schadewaldt i Friedrich Klingner potaknuti upravo Nietzscheovim djelom o grčkoj tragediji povezali su se u jednu novu „školu“ tumačenja antike koja se nije zasnivala ponajprije na kritici teksta, paleografiji, epigrafici i sl. (von Reibnitz 1). J. Mansfeld tvrdi da osuda Nietzschea u akademskim krugovima nije bila ni tako snažna ni opća (51). 
prihvaćena je i dalje fragmentirana na gotovo svim zapadnim sveučilištima što je dovelo do gubitka općeg obrazovnog ideala i samodestrukcije humanistike. Stoga Bate apelira na snažnu pomoć „prosvijetljene administracije“ na sveučilištima i fakultetima (46). Nakon skicoznog prikaza stanja humanistike, Bate se koncentrirao na studij engleskog jezika i književnosti (English studies) - koji je inkorporiranjem etike, povijesti ideja i religije, filozofije umjetnosti i sl., postao predvodnik humanistike i tako zapravo „barometar i mjera“ za druga polja unutar humanistike (47). Razmotrimo naznačeno nešto detaljnije.

Prije analize krize sâmog studija engleskog jezika i književnosti, Bate navodi najznačajnije stvari, bitno različite, koje su snažno utjecale na spomenuti studij (English studies) između 1880-ih i 1950-ih. Prvo navodi širenje polja studija (sve što je napisano o bilo čemu - povijest, politika, etika, filozofija, kozmologija može se uzeti u obzir kao sadržaj studija) i otvorenosti „idioma“ (nepostojanje „specifičnog rječnika“). To je, smatra Bate, nešto sasvim drugačije od renesansnog koncepta litterae humaniores, koji je komprimiranjem književnosti, povijesti i filozofije nastojao oblikovati karakter ljudi, pri čemu je ujedno otvorio mogućnost širenja sadržaja i otvorenost „idioma“ (47). Nadalje, Bate navodi pojavu romantizma, koji je u svojoj ekstremnijoj fazi (1880-ih i 1890-ih) skrenuo prema „esteticizmu“ - što, tumači Bate, znači da se interes usredotočio više na medium (tekstura, tonska kvaliteta, imaginacijski oblici, značenjske asocijacije), negoli na književnost i umjetnost (48). To je pak, iako je važno, dovelo do zanemarivanja „intelektualne proze“: povijesti, govorništva, filozofije. Konačno, ističe Bate, dolazi do organizacije "akademskih specijaliziranosti“ (academic specialism), kojoj su kao prototip poslužile prirodne znanosti (natural siences). Razlikujući dobro i loše oponašanje, Bate ističe da su humanističke znanosti počele od prirodnih znanosti oponašati samoimpostirajuće ograničenje, a ne otvorenost znanosti - cjelovitost i općenitost vizije. To je onda dovelo i do ograničenja u proučavanju književnosti (jedan autor, grupa autora, jedan žanr, kratko razdoblje i sl.) (49).

Bate je promjene kurikula studija književnosti koje su se počele događati uslijed „akademske specijaliziranosti“ ocrtao sljedećim fazama: prvo se između 1880-ih i 1940-ih pojavila filologija kao povijesni studij riječi (kao što se tijekom renesansnog studija nastojalo ustanoviti točan tekst klasičnih autora, tako se od 1880-ih nastojalo učiniti za svakog modernog pisca, pri čemu su se „zalagale“ pojedinačne akademske karijere). Zatim je došla nova kritika (New Criticism) (između 1950-ih i 1960-ih), koja je „srušila staro isticanje filologije“. Struktura- 
lizam je zamijenio novu kritiku, a poststrukturalizam (čiji je vođa bio „nestašni Parižanin“ Jacques Derrida) strukturalizam. Napuštanjem renesansnog ideala i prihvaćanjem progresivne specijalizacije došli smo, tvrdi Bate, do „intelektualne praznine“. Budući da nema središte, humanistika, odnosno studij književnosti širi se prema kaosu (Bate navodi i podatke o iznimnom broju doktoranada, što je, smatra, upravo jedan od važnijih simptoma samodestrukcije humanistike i studija književnosti) (49-52).

Bate onom što je ocrtao kao bezosovinsko širenje prema kaosu suprotstavlja „renesansni ideal literae humaniores“. Pritom, što je već učinio u uvodu, apelira na sveučilišne i fakultetske upravljačke strukture, ističući da je „rat“ toliko važan da se ne može prepustiti samo „generalima“ - „ekspertima“, već da s cjelokupnim kulturnim nasljeđem (zapisano ljudsko iskustvo) pripada svima nama. Konačno, navodi katalog maksima koji bi trebao biti svojevrsni lijek protiv suvremenih tendencija: prvo, cilj i tradicija književnosti jest dati cijelo iskustvo života (povijesna gibanja i pojedinčeve dileme u izboru vrijednosti); drugo, humanistika je „uvijek u krizi“ jer ona se mora baviti „izvornim grijehom" (original sin) i najuzvišenijim nadama i vizijama; tré́e, humanistika mora biti „prostodušno eklektička“ (frankly eclectic) - kao što je i naš pristup životu eklektičan; četvrto, veliki pisci su veliki interpretatori života, i izražavaju ga na različite načine (53).

Na Bateov članak ubrzo je odgovorio de Man, prvotno harvardski student, a potom jelski profesor, već spomenutim kratkim člankom The Return to Philo$\log y$. De Man napominje da otkako je studij književnosti zadobio autonomiju (a to se dogodilo, ističe de Man, ne tako davno - u kasnom devetnaestom stoljeću) legitimirao se kao humanistička i povijesna disciplina: iako doduše sličan, ipak različit od deskriptivnih znanosti - filologije i retorike. Zapravo, ambicija studija književnost uvelike je nadilazila puku deskripciju. On je, jer se zasnivao na relativno stabilnom kanonu tekstova, pružao model za povijesne znanosti čije područje nije bilo jasno određeno. Nadalje, jer mu je zadaća bila određivati značenje tekstova, njegova hermeneutička funkcija činila ga je srodnim teologiji. Konačno, kao „skladište“ različitog i opsežnog ljudskog iskustva, bio je povezan s pitanjima moralne filozofije - pitanjima vrijednosti i normativnog suda. Dakle, tehnički i deskriptivan aspekt studija književnosti kao znanosti o jeziku užlijebio se s njegovom povijesnom, teološkom i etičkom funkcijom. Tako je, zaključuje de Man, profesor književnosti imao dobre razloge da se osjeća smireno: njegova znanstvena savjest bila je zadovoljena pozitivnom strogoćom 
lingvističkog i povijesnog znanja, dok je njegova moralna, politička i, u nešto proširenom značenju, religiozna savjest bila zadovoljena primjenom tih znanja na razumijevanje svijeta, društva i sebe. Didaktičnost književnosti mogla je biti primjer za interdisciplinarnost humanističkih studija, što nije bilo inkompatibilno ni s književnom teorijom ni s književnom kritikom (de Man kao primjer navodi onu struju u studiju engleske književnosti koja seže od Samuela Taylora Coleridgea preko Ivora Armstronga Richardsa, Lionela Trillinga, Richarda Palmera Blackmura pa sve do Northropa Fryea). To, dakako, nije bilo tako u slučaju Williama Empsona ili Kennetha Burkea, odnosno nešto suvremenijih kritičara i filozofa koji su se okrenuli strukturalnoj lingvistici. Oni su, ističe de Man (The Resistance to Theory), potaknuli gnjev svojih kolega. Ilustrativan primjer takvog gnjeva upravo je Bateov članak (21-22).

Iako se slaže da se studij književnost nalazi u krizi, de Man odbacuje Bateovu dijagnozu i lijekove. Ujedno napominje da Bate smjernice koje drži ljekovitima nije ponudio u formi argumentirane diskusije, već kao apel upravljačkoj strukturi, odnosno kao nužnu „provedbu zakona“ - što, dakako, dopušta de Manu da vlastite uvide, iako znatno primjerenije od Batea, iznese također kao svojevrsni apel upravljačkim sveučilišnim strukturama. De Man svoje viđenje započinje jednim „specifičnim nastavničkim iskustvom“, a ne, kako tvrdi, filozofskim pretpostavkama. Riječ je o nastavi Bateova kolege Reubena Browera, vrlo udaljenog od francuskih teoretičara, točnije o kolegiju The Interpretation of Literature (na Harvardu, pa i u široj struci, poznat kao HUM 6). Brower je, naime, od studenata tražio da o tekstu o kojemu trebaju pisati ne pišu ništa što ne mogu izvesti iz sâmog teksta o kojemu pišu. Odnosno, studenti nisu smjeli napisati nikakvu tvrdnju koju ne bi mogli poduprijeti jezikom koji se pojavljuje u tekstu o kojemu pišu. Konceptualan i terminološki aparat sveden je na minimum. To jednostavno pravilo imalo je dalekosežne didaktičke posljedice: pokazalo se da sâmo čitanje može transformirati kritički diskurs na način koji se činio duboko subverzivan onima koji su mislili da je studij književnosti svojevrsna zamjena za poučavanje teologije, etike, psihologije i intelektualne povijesti. Dakle, razumijevanje nije primarno estetičko (u smislu unaprijed danih mjerila), već ga određuje „analitička strogost“ sâmog našeg diskursa o književnosti (The Resistance to Theory 23-24). ${ }^{12}$

${ }^{12}$ De Manovo čitanje filozofskih tekstova bez prethodnih koncepata i logičkih artikulacija potaknulo je polemiku s R. Gaussom, koji je smatrao da de Manova uporaba određenih detalja teksta, fraza, tropa i sl. može značiti da filozofija ne vlada svojim konceptualnim alatima (R. Gauss, A Response to Paul de Man i P. de Man, A Reply to Reymond Geuss, u: Critical Inquiry X, 2, 1983.) (usp. Brusar 74). 
Očito, smatra de Man, iako su motivi i terminologija različiti, Browerovo nastavničko iskustvo ne razlikuje se bitno od modernih teorija. Potom slijedi najreferentnija misao de Manova članka: „Okret prema teoriji dogodio se kao povratak filologiji, ispitivanju strukture jezika prije negoli značenja koje proizvodi“ (The Resistance to Theory 24). Kao primjer takvih tendencija de Man navodi Foucaltovu knjigu Les mots et les choses (1966), koja tematizira odnos jezika i stvarnosti. Ali, napominje de Man, to se ne čini iz perspektive filozofijske spekulacije, već znatno pragmatičnije: iz perspektive socioloških znanosti i filologije. Također i Derrida, iako se čini znatno „filozofičniji“, naglašava empirijsku moć jezika usuprot intuiciji i spoznaji - što pokazuje njegova kritika fenomenologije. Čak i u slučaju Nietzschea, ističe de Man, naglasak je na Nietzscheu filologu, a ne Nietzscheu "egzistencijalnom nihilistu“ (The Resistance to Theory 24). ${ }^{13}$

Za Batea je, dakle, filologija Textkritik i jedna „akademska specijaliziranost“, koja koincidira s institucionalizacijom studija književnosti na američkim sveučilištima, počevši od 1880-ih godina. Nju slijede specijalizirane književne teorije, tehnokratska modernost - koja je dovela do alijeniranja filološke prakse od renesansnog ideala. Za de Mana filologija se bavi ispitivanjem sâme strukture jezika, pa stoga koincidira s retorikom, lingvistikom, odnosno filozofijom jezika. Za potonju tendenciju (ispitivanje strukture jezika) jedan je od ključnih autora upravo Nietzsche.

IV.

Pitanje (koje postavlja književna teorija) može li estetsko mjerilo biti kompatibilno s jezičnim strukturama koje stvaraju entitete iz kojih se mjerila izvode, ističe de Man, nikada ne prestaje proganjati svijest pisaca i filozofa. Dakako, nipošto nije utvrđena činjenica da su estetska mjerila i jezične strukture inkompatibilne. Ono što je utvrđeno zapravo je da kompatibilnost (ili nedostatak kompatibilnosti) estetskog mjerila s jezičnim strukturama koje stvaraju entitete iz kojih se mjerila izvode ostaje otvorenim pitanjem. Zatvaranje tog pitanja, makar i zbog najboljih namjera, nije dobro. Stoga studij književnosti treba biti ponajprije studij retorike i poetike, a ne hermeneutike i povijesti (de Man, The Resi-

${ }^{13} \mathrm{O}$ tome da većina suvremenih ničeanaca tendira biti filolozima (književnim povjesničarima), a ne filozofima usp. Babich, „Nietzsche’s Antichrist“ 136. 
stance to Theory 25-26). ${ }^{14}$ Nietzsche je problem (sokratičke) znanosti također identificirao kao stvar jezika i hermeneutike pa stoga i kao problem „loše 'filologije'“ (schlechten 'Philologie') (KSA 5, 37; usp. Babich, „Nietzsche's Philology“ 193). Naime, sokratički znanstvenik kreće se u pojmovima a da ne zna da su oni samo ispražnjene metafore. „Laž“ intelekta nalazi se u pojmovnoj nedohvatljivosti metafizički, a ne biologijski mišljenog života. Istodobno (što korespondira s dionizijsko-apolonijskom dijalektikom) intelekt stoji u službi volje života, koja počiva na iluziji koja održava život. Logička volja, volja za „istinom“, samo je usahnuli ostatak izvorno umjetničkog (Fink 39-40).

U Über Wahrheit und Lüge im aussermoralischen Sinn (1873) - locus classicus Nietzscheove „filozofije jezika“ - postavlja se epistemološko pitanje: Odgovaraju li stvari njihovu označitelju? Je li jezik adekvatan izraz svih stvarnosti? (Nietzsche, „O istini i laži“ 10; KSA 1, 879). Odgovori su oštro nijekanje: „Neće li se zadovoljiti istinom u formi tautologije, tj. praznim ljuskama, vječno će iluzije prodavati pod istine.“ (10; KSA 1, 879). Jezik je, tvrdi Nietzsche, proizvod

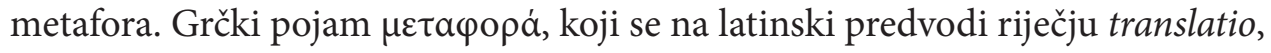
Nietzsche za razliku od retoričara ne smatra pukim „prijenosom“, zamjenom riječi drugom riječi (immutatio verborum), već ističe da se translatio događa prije sâmog jezika. Stoga je osnovno pitanje na koji se način podatci osjetne percepcije prenose u jezik. Nietzsche razlikuje dvije metafore: prva metafora koju um koristi u spoznajnom činu zapravo je prijenos osjetne percepcije u predodžbu, drugom metaforom može predodžba biti prenesena u jezik. Prema Nietzscheu, prva i druga metafora su skokovi iz originalne sfere u radikalno drugačiju i novu. Ono što se, dakle, događa prije prve riječi zapravo je translatio - skok. U tom smislu, dakle, jezik nije ništa drugo nego proizvod metafora, a „stvar po sebi“ (Ding an sich) koju metafore denotiraju ne može biti spoznata. Samo čovjek je jedva svjestan da se kada govori koristi metaforama, stoga se originalne metafore s vremenom „iscrpe“. Znanstveno pojmovlje pripada posljednjem

\footnotetext{
${ }^{14}$ Iako ističe da „retorika radikalno zaustavlja logiku i otvara vrtoglave mogućnosti referencijalnih aberacija“, P. de Man ne odbacuje mogućnost značenja (Allegories of Reading 10). On primjenom „epistemologije retorike“ nastoji pokazati da su čitanje, razumijevanje i tekstualnost složeniji od pretpostavki kako se do značenja može doći mimo retorike ili kako je do značenja uopće nemoguće doći (Brusar 70). Ilustrativan primjer de Manove „opreznosti“ njegovo je čitanje Nietzschea. Naime, ako čitamo Nietzschea retoričkom sviješću koju nam nudi njegova vlastita „teorija retorike“, napominje de Man, uvidjet ćemo da struktura njegova djela podsjeća na beskrajno ponavljajuću gestu umjetnika „koji ne uči iz iskustva i stoga uvijek iznova zapada u istu zamku“. Ono pak, ističe de Man, što je najteže ustvrditi jest da je „alegorija pogrješke“ pravi model filozofskog rigorizma (Allegories of Reading 118).
} 
stadiju tog razvoja. Ono je reziduum metafora. $\mathrm{U}$ tom smislu Nietzsche piše o iluziji, obmani, izvrtanju, snovima (O istini i laži 12-13).

Budući da namjerno reaktivira metaforičnost jezika, pjesništvo je u prednosti pred znanošću. U pjesništvu se „istrošene“ metafore, koje se inače ne prepoznaju kao takve, zamjenjuju izvornom metaforičkom intencijom za Anschaulichkeit. Pjesništvo se koristi metaforama na način igre i ironije. Metafore u pjesništvu ponovno zadobivaju svoj izvorni spontanitet. Pjesništvo je namjerna obmana - a upravo takvom obmanom ono korespondira s iluzornim karakterom jezika. Otud poznata Nietzscheova tvrdnja u Also sprach Zarathustra: „[...] die Dichter zu viel lügen“ (68). Tvrdnjom da pjesnici odveć lažu, Nietzsche, dakako, nije mislio na moralni nedostatak pjesnika. Pjesnici ne lažu zato što ne vole istinu. Usuprot, metaforički karakter jezika sili ih da lažu. Samo, lažući namjerno - koristeći se metaforičkim karakterom jezika eksplicitno - oni su bliže istini negoli oni koji lažu bez ikakve svijesti o tome (Allemann 105-07). ${ }^{15}$

Tako gledajući, metafora je, možemo zaključiti, epistemička figura koja metonimički izražava „sintetski sud“ (Kant). Za Nietzschea - kao i za Kanta - noumenon, Ding an sich, jednostavno ne može biti spoznata (Babich, „The Science of Words“ 52-53). Otud, smatram, u Die Geburt der Tragödie Nietzscheovo odbacivanje znanstvenog aparata (Fußnotenphilologie) i okretanje aforističkom, enigmatičnom, ironijskom - što je za Wilamowitza bilo nedopustivo i izdaja znanstvene paradigme, a za De Mana je riječ o inovativnoj semantičkoj disonanci po kojoj značenje ostaje izvan dosega logike sâmog teksta i tjera čitatelja da uđe u beskrajan proces dekonstrukcije (Allegories of Reading 99). ${ }^{16}$

Nepotrebno je spominjati da su upravo Nietzscheove tvrdnje o jeziku potakle autore poput Heideggera i Derridae (teorijska jezgra njihovih tvrdnji, ističe njihov kritičar Paul Ricœur, tobožnji je dosluh metaforičkoga para „stvarnog“ i „prenesenog“ i metafizičkoga para „vidljivog“ i „nevidljivog“, 334). Dovoljno se prisjetiti Derridaine tvrdnje iz njegove vrlo referentne studije Mythologie blanche (1971) da je metafizika „u sebi samoj izbrisala bajoslovni prizor koji ju je

${ }^{15}$ B. Allemann smatra da je Nietzscheov radikalni skepticizam, s gledišta povijesti filozofije, zapravo zastario projekt jer nakon fenomenoloških studija nema više „naivnog" realizma protiv kojega se Nietzsche borio (107).

${ }^{16}$ De Man smatra da je Nietzsche, zajedno s Marxom i Freudom, poduzeo radikalno odbacivanje genetičke teleologije romantičarskog idealizma (iz čega proizlazi i siromaštvo narativne koherencije Nietzscheova djela o tragediji), što eksplicira čitanjem Die Geburt der Tragödie (Allegories of Reading 79-102). 
proizveo, ali koji i dalje ostaje djelotvoran, nemiran, ispisan bijelim crnilom, nevidljiv i prekriven u palimpsestu" (4). Dakle, kada de Man tvrdi da Foucault i Derrida ne stavljaju naglasak na Nietzschea filozofa („egzistencijalnog nihilista“), već na Nietzschea filologa - riječ je zapravo o kritičkoj oštrici s obzirom na Bateovu konstataciju da se Derrida nikada ne okreće doista najvažnijim filozofima, osim da zgrabi ustajali pesimizam koji poriče mogućnost pronalaženja istine (pritom navodi upravo Nietzschea) (Bate 52) - nije posve točna. Foucault i Derrida, pa i mnogi drugi njima misaono bliski autori pozivaju se upravo na Nietzschea filozofa (jezika), na Nietzschea koji je na sâmom početku svoje znanstveno-nastavničke karijere, na nastupnom predavanju Homer und die klassische Philologie 28. svibnja 1869., preokretanjem Senekine misli, ustvrdio: „Philosophia facta est quae philologia fuit“ (FS 5, 305). Upravo eksplikacija tvrdnje da je ono što je bilo filologija postalo filozofija (odnosno intuitivno viđenje tragičkog svjetskog bivanja), osnova je Nietzscheova djela.

V.

Iako je de Man u svom članku mnoge stvari izveo na čistac, što se tiče filologije - ističe Ziolkowski - ostao je upadljivo „tanak“ i „mutan“ (Metaphilology 241). Štoviše, nastavlja Ziolkowski, njegova nedorečenost je autosubverzivna jer je de Man tvrdio da je filolog, a ne filozof (241; usp. Rosso 791). Sâmu riječ filologija de Man u svom članku navodi tek dva puta: jednom je izjednačava s gramatikom iz srednjovjekovnoga triviuma, drugi puta (riječ je o već spomenutom - citiranom topičkom mjestu) izjednačava ju, tvrdi Ziolkowski, s lingvistikom (242). Međutim, koliko god de Manova uporaba riječi filologija bila opskurna, „tanka“ i „mutna“ - ili baš stoga što je bila takva! - njegov je apel za „povratak filologiji“ potaknuo suvremene rasprave o filologiji, što je uostalom posvjedočio sâm Ziolkowski. Štoviše, de Manov članak, koji je ubrzo postao „točka okreta“ u suvremenom itinerariju pojma filologije, nije potaknuo samo pojavu nove filologije već i razne „povratke filologiji“ (usp. Patterson 231-244; Said 57-84 i Vadde 461-465) te poplavu različitih filologija: „reciklirana filologija“ (Knapp 1993), „kozmopolitička filologija“ (Paulson 2001), „postfilologija“ (Warren 2003), „,isjunktivna filologija“ (Robins 2004), „radikalna filologija“ (Gurd 2005), „filologija budućnosti“ (Pollock 2009), „oslobađajuća filologija“ (Dumitrescu 2013), „kozmopolitska filologija“ (Horta 2013), „filologija u novom ključu“ (McGann 2013,) „svjetlucava filologija“ (Warren 2014), „posthumana filologija“ (Kay 
2014), „divlja filologija“ (Naithani 2014) i „svjetska filologija“ (Pollock 2015) (usp. Orlemanski 173-174 i Warren, „Introduction: Relating Philology“ 286). ${ }^{17}$

Nažalost, Ziolkowski je onu drugu, stariju i za de Manov apel povratka filologiji, pa stoga i za suvremenu pojavu raznih filologija ishodišnu polemiku (Nietzsche - Wilamowitz-Möllendorff - Wagner - Rohde) ostavio postrance. Da ju je pažljivije proučio, uvidio bi zašto je de Manova uporaba riječi filologija „tanka“ i „mutna“, uvidio bi da je za razliku od filozofa (teoretičara) (de Man) koji je tvrdio da je filolog, tada filolog (Nietzsche) tvrdio da je filozof (teoretičar), i da se upravo u tim naoko suprotnim tendencijama krije zapravo točka preklapanja: Filozofski ili teorijski sistemi ne shvaćaju se kao utemeljenje istine, već kao interpretacije čije utemeljujuće vrijednosti mogu kao takve biti procjenjivane i čiji je status bliži metafori ili retoričkom tropu negoli čistom konceptu, bezvremenskom apstraktnom osnovu. Drugim riječima, ukazuju na gubitak bilo kakvog utemeljujućeg ili transcendentalnog označitelja (koji je u zapadnoj tradiciji poprimio različita imena: bog, esencija, egzistencija, supstancija, subjekt, čovjek itd.) koji bi usredištio filozofski ili teorijski sistem u ishodišnu točku ili trenutak „prisutnosti“. Stoga se čini sasvim primjerena konstatacija Jonathana Cullera da je kod de Mana (i Nietzschea), pa onda posljedično i u mnogim suvremenim „filologijama“ riječ o „protu-temeljnoj filologiji“ (anti-foundational philology) (49-52).

Iako je ranije sumnjao da postoji „srednje tlo između dekonstruktivnih ciljeva nekih teorija i rekonstruktivnog projekta filologije?“ („What is Philology“ 11), Ziolkowski je svoj vrlo referentan članak Metaphilology završio apelom: „Bilo da filologiziramo ili metafilologiziramo, volimo logos!“ (272). Što je apelom mislio, može li se voljenjem logosa pronaći „srednje tlo“ između suprotnih tendencija, u konačnici što je mislio pod bremenitom riječi logos, Ziolkowski dakle nije objasnio. Ipak, držim da je poziv na „voljenje logosa“ - ukoliko ga se smjesti i protumači u onoj tradiciji na koju se iznimno oštro okomio Nietzsche, a poststrukturalistički mislitelji (primjerice, Jean-Luc Nancy) nastojali „dekonstruirati“ (dakako, riječ je o kršćanstvu, koje je Nietzsche nekritički povezao s

\footnotetext{
${ }^{17}$ Naravno, filologija je i ranije bila u opticaju, bilo pri imenovanju studija kao što su klasična filologija, bilo kao riječ u nazivima znanstvenih publikacija (Journal of English and Germanic Philology, American Journal of Philology, Classical Philology, Harvard Studies in Classical Philology, Modern Philology, Neuphilologische Mitteilungen, Philological Quarterly, Philologus, Romance Philology, Zeitschrift für deutsche Philologie, Zeitschrift für romanische Philologie, Filologija), ali filološki koncepti nisu bili znatnije analizirani.
} 
platoničkom tradicijom) - može biti smjerodavan, doduše ne za pronalaženje „srednjeg tla“ između „rekonstruktivnog projekta filologije“ (kakav je zagovarao Wilamowitz) i „dekonstruktivnih ciljeva nekih teorija“ (kakve je zagovarao de Man), već za viđenje jedne cjeline svijeta, pa stoga i filologije unutar njega. Tâ cjelina je utjelovljena Riječ („Raspeti“) koja nije, kako je mislio Nietzsche, puki simbol patnje koja se odriče zemlje ukazujući na nebo i životu neprijateljski moral. Drugim riječima, „Raspeti“ nije puki simbol utopijskog „stražnjeg“ svijeta religije i metafizike usuprot kojemu se nalazi Dioniz (također bog patnje, ali patnje koja je samo druga strana naslade, ponovnog vraćanja, bog dvoličnog života, gradećeg i razarajućeg). „Raspeti“ je simbol u smislu staviti zajedno ( $\sigma v v-\beta a ́ \lambda \lambda(\omega)$ - biti jedno: logos-tijelo.

VI.

Pomak od klasičnih shvaćanja logosa (kozmički princip koji uvodi red u svijet, stvaralački um, emanacija vječnog zakona) prema jednom novom, antimetafizičkom, pokazuje klasično mjesto iz Goetheova Fausta. U trenutku kada

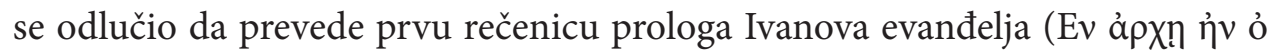
$\lambda$ ójoఢ) na „njemački njegov mili“, učenjak filolog (retoričar, logičar i metafizičar) Faust nije se mogao odlučiti za pravo značenje. Odbacujući prijevod Martina Luthera (Wort - „,riječ“), prvo pomišlja da logos prevede riječju „smisao“ (Sinn), zatim „snaga“ (Kraft) da bi se u konačnici odlučio za „čin“ (Tat) („Ich schreibe: Im Anfang war die Tat", 1237).

Charles Harold Dodd - koji je svoju iznimno referentnu studiju o Ivanovu evanđelju The Interpretation of the Fourth Gospel (1953) započeo upravo naznačenim mjestom iz Fausta - ustvrdio je da je Faustova poteškoća daleko od poteškoće pukog prevođenja, pa čak i od uobičajeno shvaćene egzegeze. Pitanje

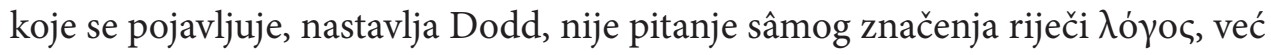

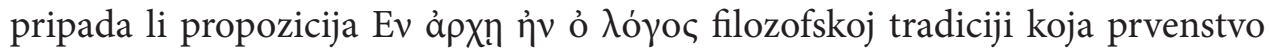
daje apstraktnoj misli, ili onoj koja prvenstvo daje moći, ili pak sâmoj riječi kao sredstvu komunikacije. Odgovor se može pronaći, osnovna je Doddova teza, jedino ako se ima na umu značenje/smisao cijelog evanđelja (3-4). Iz tako zacrtanog smjera Dodd zaključuje da se autor prologa poslužio hermetičkom književnom tradicijom, helenističkim judaizmom Filona Aleksandrijskog i rabinskim judaizmom (odbacuje tezu - koju su zastupali Mark Lidzbarski i Rudolf Bultmann - o sloju mandeističkog gnosticizma u prologu) da bi bio komuni442 kativan adresatima oblikovanim različitim tradicijama. Logos iz prologa, stoga, 
ujedno znači i „Riječ“ (Tora kao riječ Božja, proročka riječ), božanska mudrost, ishodišni princip, kreativna moć kojom nastaje i održava se kozmos. Naracija o životu Isusa iz Nazareta, koja slijedi nakon prologa, povijest je logosa. Propozi-

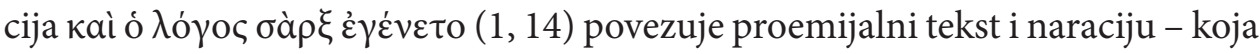
je sačinjena od dva dijela: knjige sedam znamenja (simbola) i muke (284-85).

Književni teoretičar Frank Kermode, iz jednog drugačijeg metodološkog polazišta (tekstualističkog), postavio je pitanje što prolog sa svojim unutarnjim odnosima, jezičnim kompleksom i povezanošću sa susljednim narativnim sklopom znači nama danas. Kermode se pritom pozvao prvo na Ivana Zlatoustog (Krizostom) - koji je u svojim komentarima Ivanova evanđelja istaknuo važnost sâmog teksta (Patrologiae Graecea 1862, 29), a zatim i na Augustinovu tvrdnju da mi tekst razumijemo prema svojim ograničenim mogućnostima (riječ je ne samo o tome tko smo nego i o tome kada smo) (Patrologiae Latinae 1841, 1569) (usp. Kermode 441 i 444). Prema Kermodeu, središnju os prologa čine riječi ĩv

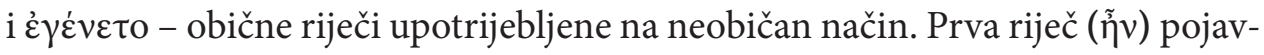
ljuje se tri puta („,riječ bijaše...“; „... bijaše s Bogom“; „bijaše Bog“), kao i druga

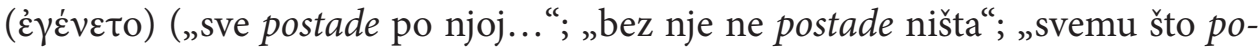
stade..."). Dakle, tri „postojanja“ naspram tri „bivanja“ od vječnosti. Tri antitetička odnosa koja upućuju na stvoritelja i stvorenje zapravo su liminalnost koja

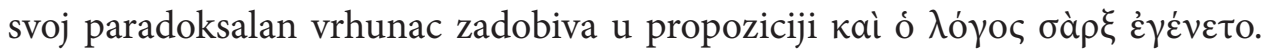
Liminalna antiteza prologa, ističe Kermode, ekstendira se nadalje u evanđeosku naraciju $(445,447)$. Tako su narativne epizode impostirane kao tekstovi koji intendiraju „dublje značenje“: one su reprezentacije vječnog u odnosu na ono prijelazno, manifestacija onog vječnog u svijetu koji nastaje (453).

Očito, i za bibličara Dodda i za književnog teoretičara Kermodea četrnae-

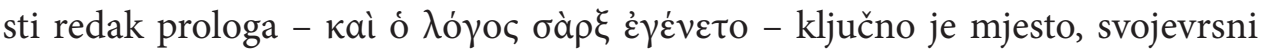
hermeneutički ključ. Držim da su u pravu! Stoga ću nadalje naznačiti osnovne smjernice razumijevanja filologije polazeći upravo od četrnaestog retka prologa Ivanova evanđelja. Pritom puko filološko seciranje imenice $\lambda$ ójoৎ i glago-

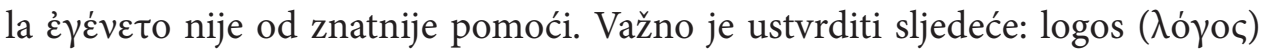
jest tijelo ( $\sigma a ̀ \rho \xi)$. Dakle, logos nije samo tekst (evanđeoska naracija), već tkivo, meso, kosti, krv, žile - püt. 
VII.

Tvrdnja da logos jest püt/tijelo (logos-tijelo) u nekoj mjeri odgovara kršćanskoj egzegetskoj tradiciji, koja je usuprot stoičko-platoničkoj egzegezi (allegoria in verbis) isticala faktualnu alegoriju (allegoria in factis). ${ }^{18}$ Stoičko-platoničko tumačenje zasniva se na supstituiranju „doslovnog smisla“ (kore) prenesenim (jezgra). Faktualna alegorija zasniva se na „izvanjezičnoj zbilji“ (littera) koja se ne smije supstituirati alegorijskim smislom. Budući da su medijevalni autori littera dovodili ne samo u svezu s historia već i s corpus („Littera est sicut corpus hominis: quae littera est ipsa historia“, Patrologia Latina XCVI, 985 A), kod allegorie in factis nije riječ samo o novom hermeneutičkom modelu koji je impostiran usuprot platoničkom razlikovanju mnijenja i pravog znanja (egzegeze kata doxan i kata alêtheian, de Lubac 102), ${ }^{19}$ već i o implicitnom novom shvaćanju tijela (i, dakako, povijesti).

Tijelo dakle nije puka kora (označitelj) koja se odbacuje da bi se dohvatila jezgra (označeno). Drugim riječima: tijelo nije znak za ono odsutno, ono ne otvara nepregledno poprište razlika jer nije „izvanjsko“ onomu "duhovnom“, nije "nadomjestak“ (supplément) koji „nema sposobnost da pribavi odsutno prisustvo (péresence)“ (Derrida, Gramatologija 203). Tijelo nije ni puko hilemorfičko (utisnutost forme, morphé, u materiju, hyle), ni fenomenologijsko (tijelo je medij i oruđe uprisutnjenja svijesti sâmoj sebi), ni konstruktivističko (tijelo je „upisna ploha“ koja se „ispisuje“ iz vanjskog prostora društvenih institucija, režima institucijske moći), ni „Tijelo bez Organa“ (A. Artaud i J. Deleuz), ni ekstenzija i ekspozicija, pojava sâmoga sebe (J.-L. Nancy). Tijelo je, kršćanski mišljeno, sakrament - mysterium magnum. Za razliku od znakova moderne umjetnosti koji nemaju nikakvu fiksnu referenciju, logos-tijelo u smislu sakramenta prisutnost je koja je ujedno svojevrsna odustnost. Riječ je o logosu koji

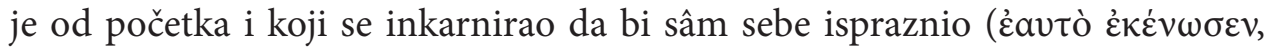
Ef 2,7 ) i tako postao odsutno-prisutan (uskrsnuće/uzašašće). Dakle, nije riječ o ispražnjavanju do onog nihil, bestemeljnosti, božanskom samoalijeniranju,

${ }^{18}$ Kršćanski pisci bili su itekako svjesni da alegorija nije samo allegoria in factis nego zapravo allegoria facti et dicti: u Bibliji Bog govori riječima o djelima/događajima koje je providonosno vodio (historia). Otud je proizišla i složena epistemološka problematika (Nemetz 76-89).

${ }^{19} \mathrm{Na}$ distanciranost kršćanstva prema platoničkoj tradiciji ukazuje već teološka formula creatio ex nihilo, koja se uobličila u patrističkoj književnosti pri kritičkom sučeljavanju upravo s platoničkim učenjem o modelu svijeta. Augustinove Ispovijesti ilustrativan su primjer s obzirom na logos. Naime, Augustin piše da je kod neoplatonista pročitao da u početku bijaše logos, i da logos bijaše kod Boga, i da logos bijaše Bog, ali nigdje nije našao da je logos postao tijelom (VII, 9). 
ispražnjavanju Boga od sebe sâmoga, već o apsolutnoj parusiji Oca po Sinu u Duhu. Pritom nije riječ o odnosu koji implicira hijerarhijsku strukturu u kojoj podređeni član opreke proizlazi iz nepotpunosti imanentne njezinu osnovnomu članu i tako otvara nepregledno poprište razlika, već o nehijerarhijskoj perihore$z i$ (međuprožimanju). U perihoretičkom odnosu nema više dva hijerarhizirana člana, već tri „istobitna“ (homousios).

Budući da se logos-tijelo ekstenziralo u beskraj (uskrsnuće/uzašašće), pri čemu nije izgubilo svoju partikularnost (identitet raspetog i uskrslog tijela), „dohvaćanje“ logos-tijela ne ostvaruje se pukim „dodirom“, nego kao i dohvaćanje littera u patrističkoj i medievalnoj egzegezi: vjerom (per fidem). Upravo tû jer i kršćanski pisci i Nietzsche u središte stavljaju volju - na jedan iznenađujući način susreću se i snažno razdvajaju kršćanstvo i njihov oštar kritičar (kao, uostalom, i pri isticanju tijela usuprot platoničkoj umnoj spoznaji): kršćanski pisci volju smatraju „pračinom“ vjere, Nietzsche kao volju za moć - što je u konačnici rezultiralo apsolutnim pravom volje da raspolaže tijelom, što je tijelo postavilo u poredak imanja. Da se nakratko vratim Goetheovu Faustu.

Faust, kojemu je sav filološki trud mrtva učenost i puki „pergament“ (566), učenjak koji je bio zasićen nekorisnim starim znanjem pa se utekao nadahnuću „Zemnog duha“ (Geist der Erde) anticipirao je Nietzschea za kojega „nema 'bitka' iza činjenja, djelovanja, bivanja; 'činitelj' je činjenju samo pripjevan - činjenje je sve“ (KSA 5, 279; usp. Barbarić 81). Ukoliko pak Goethea čitamo polazeći od de Manove tvrdnje da pisac kaže i nešto što nema namjeru da kaže, štoviše da „najveće sagledavanje“ izriče upravo u trenutku „najveće zaslijepljenosti“ („Blindness“ 109), onda možemo pomisliti da Faustov prijevod prvog retka Ivanova prologa anticipira i Derridau za kojega su čin i proces pisanja (écriture) „emancipacija značenja u odnosu na svako aktualno područje percepcije“ (Pisanje 13). U tom smislu Faust je pri ekstatičnom nadahnuću postao žrtva pisanja („Ich schreibe“) koje potkopava značenje. Držim da je i sâm de Man upravo u trenutku zaslijepljenosti izrekao misao o logosu koja je zapravo vrlo bliska klasičnim tumačenjima: spoznajna funkcija nalazi se u jeziku. Jezik, dakle, prethodi spoznavanju, on je svojevrsna zakonitost, temeljno načelo koje omogućuje shvaćanje. Ali - za razliku od klasičnih tumačenja - iz jezika koji je vrsta svijesti bez subjekta, prema de Manu, ne proizlazi logika, već retorika: "retorika zaslijepljenosti“ (rhetoric of blindness). 
Naznačene tendencije zapravo su na tragu novovjekovnih pokreta zapadnjačke elite (alkemija, hermetizam, novoplatonizam, deizam, panteizam) za koje su sva imena „dim i zvek“ (Goethe). One su pokušaj dokrajčenja metafizičke tradicije dekonstrukcijom tri stratuma: tijela, označavanja i subjektivacije.

\section{VIII.}

Polemike Nietzsche - Wilamowitz - Wagner - Rohde i Bate - de Man pokazale su dvije osnovne tendencije ne samo u shvaćanju filologije već i humanistike. S jedne strane, Wilamowitz i Bate smatraju da filologija i humanistika trebaju biti rekonstrukcijske, da se trebaju oslanjati na sensus communis (što je za Batea „prekrasna kvaliteta“ čija je bît da može „zadržati u umu nekoliko stvari istodobno“, 53), da je njihova povijest stalan napredak; s druge strane, Nietzsche i de Man smatraju da filologija treba biti dekonstrukcijska, da se treba zasnivati na svojevrsnoj sumnji u jezik. Za Nietzschea jezik sâm je metafizičan, on ima „grubu fetišku moć“, jer upravo on fiksira činitelja i čin, supstanciju, kauzalitet, volju, bitak. Jezik jest razumijevanje bitka - ali to za Nietzschea znači da je ispunjen fikcijama, gramatičkim pojmovima (Fink 174). Jer je kršćanstvo povezao s platonizmom, za Nietzschea biti filolog znači biti antikršćanin, viriti „iza svetih knjiga“, govoriti: „Obmana“ (KSA 6, 226). Rekonstrukcijske tendencije svele su filologiju na kultiviranje subjektivnosti, „mrtvo znanje“, učenjaštvo, znanost o kulturi; ${ }^{20}$ dekonstrukcijske tendencije odbacile su klasičan odnos logike i retorike u oblikovanju znanja i istine te su svele filologiju na proučavanje jezika kao svojevrsne svijesti bez subjekta, pa u tom smislu na nekakvo mistično, faustovsko znanje.

Tvrdnja da logos jest tijelo podriva i rekonstrukcijske (humanističko-prosvjetiteljske tendencije zasnovane na ideji sensus communis i historijskom pozitiviz$\mathrm{mu}$ ) i dekonstrukcijske tendencije (zasnovane na „razgradnji“ metafizičko-platoničke tradicije). Za rekonstrukcijske tendencije logos-tijelo je skandalozno otjelovljenje istine, svojevrsni bodying, lokaliziranje istine u partikularnu točku povijesti. Za dekonstrukcijske tendencije logos-tijelo je opasno blisko koncepciji tijela kao unaprijed zadanom entitetu, otjelovljavanju forme, performativnom

\footnotetext{
${ }^{20}$ Iznimno referentan njemački romanist Erich Auerbach, oslanjajući se na Hegela, zagovarao je filologiju kao znanost o kulturi (Philologie als Kulturwissenschaft) koja „nije ista kao ona stara“ (6; usp. Barck - Treml 2007). E. Auerbach je poput Ericha Kahlera smatrao da se književnost treba shvatiti kao unutrašnji život povijesti, pa se onda i književna kritika treba tumačiti kao otkrivanje „unutrašnje volje" (inner will) književno-povijesnih razdoblja. O kretanju filologije od Textkritik (izrada kritičkog izdanja) pa sve do Geistesgeschichte (povijest ideja) usp. Altschul 2010.
} 
činu noetičkog subjekta. Da je riječ o svojevrsnom „trećem putu“, neskrivenosti

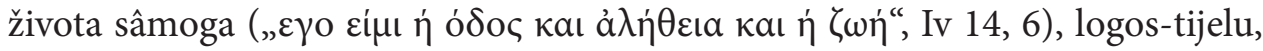
nadam se da sam uspio naznačiti.

Da zaključim: filologija (dakako, iz naznačene - kršćanske - vizure) ne iscrpljuje se ni u rekonstrukcijskim ni u dekonstrukcijskim tendencijama, već je ona ponajprije svojevrsno erotičko znanje. Drugim riječima, njezin najbitniji alat nije skupina humanističkih disciplina (povijesnih, književnopovijesnih, jezikoslovnih), ni ničeanska ästhetischen Wissenschaft kojom se dohvaća tragička bît svijeta, ni strategije razgradnje teksta, „retorika zaslijepljenosti“, već vjera,

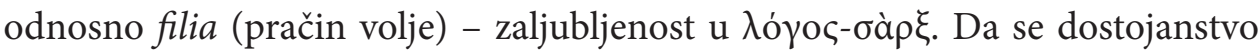
filologije zasniva upravo na filia, filološkoj tradiciji nije nepoznato. Dovoljno se prisjetiti platoničke vizije Marcijana Kapele - koji je Filologiju uzdigao na rang božice činom vjenčanja (De nuptiis Philolgiae et Mercurii) pri čemu su Gramatika, Retorika i Dijalektika vjenčani darovi. Dakako, filia na koju sam mislio nije platoničko erotičko znanje, već „adekvacija“ tijela filologa i logos-tijela. Iz takve adekvacije „rađa“ se (jedno) Tijelo. To pak Tijelo „rađa“ „sveti tekst”, kojemu pristupa klasičnim filološkim instrumentarijem (povijesno-kritička metoda) i svojevrsnom „retorikom zaslijepljenosti“ (pluralitet tumačenja „svetog teksta“ bez obzira na intenciju autora; usp. Augustin 297, 301-303). U tom smislu biti filolog znači biti kršćanin. Znakovito je da na kraju, u završnom pozdravu kršćanima Rima, autor Poslanice Rimljanima navodi i nekog Filologa: „ảotáo $\theta \varepsilon$

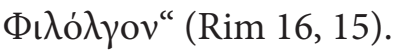

Dakako, iz naznačene vizure apel institucijama besmislen je. Ostaje samo kerigma upućena svakom pojedincu, odnosno volji i humanističko-prosvjetiteljski centriranog subjekta i decentriranog, performativnog postmodernog subjekta.

\section{Literatura}

Allemann, Beda. „Metaphor and Antimetaphor.“ Interpretation: the Poetry of Meaning, uredili Stanley Hopper i David Miller, Harcourt, Brace \& World, 1967, str. 103-23.

Altschul, Nadia. „What is Philology? Cultural Studies and Ecdotics.“ Philology and its Histories, uredio Sean Gurd, Ohio State University, 2010, str. 148-63.

Augustin, Aurelije. Ispovijesti. Preveo Stjepan Hosu, Kršćanska sadašnjost, 1994.

Aurebach, Erich. „Philology and Weltliteratur.“ The Centennial Review, sv. 13, br. 1, 1969, str. 1-17.

Babich, Babbette. „The Science of Words or Philology: Music in the The Birth of Tragedy nad the Alchemy of Love in The Gay Science." Rivista di estetica, sv. 28, br. 1, 2005, str. 47-78. 
---. „Nietzsche's Philology and Nietzsche's Science: On the 'Problem of Science' and 'fröhliche Wissenschaft'." Metaphilology: Histories and Languages of Philology, uredio Pascale Hummel, Philologicum, 2009, str. 155-201.

---. „Nietzsche's Antichrist: The Birth of Modern Science out of the Spirit of Religion.“ Jahrbuch fur Religionsphilosophie, sv. 13, 2015, str. 134-54.

Barbarić, Damir. „Pjesnički um.“ Nietzscheovo nasljeđe, uredio Damir Barbarić, Matica hrvatska, 2002, str. 71-92.

Barck, Karlheinz i Martin Treml. „Erich Auerbachs Philologie als Kulturwissenschaft.“ Erich Auerbach, Geschichte und Aktualität eines europäischen Philologen, uredili Karl-Heinz Barck i Martin Treml, Kulturverlag Kadmos, 2007, str. 9-32.

Bate, Jackson Walter. „The Crisis in English Studies.“ Harvard Magazine, sv. 85, September-October, 1982, str. 46-53.

Benne, Christian. Nietzsche und die historisch-kritische Philologie, Walter de Gruyter, 2005.

Bilić, Jakša. „Filologija i filozofija: Polemika oko Rođenja tragedije iz duha glazbe." Anthropos, br. 1-2, 2013, str. 9-25.

Brusar, Krešimir. „Retorika, estetika i ideologija u književnoj kritici Paula d Mana.“ Književna smotra, sv. 32, br. 1-2, 2000, str. 69-75.

Calder, William Musgrave. „The Wilamowitz-Nietzsche Struggle: New Documents and a Reappraisal.“ Nietzsche-Studien, sv. 12, br. 1, 1983, str. 214-54.

Culler, Jonathan. „Anti-Foundational Philology.“ On Philology, edited Jan Ziolkowski, Pennsylvania State UP, 1990, str. 49-52.

de Lubac, Henri. Meideval Exegesis II. Preveo Edward Macierowski, William B. Eerdmans Publishing Company - T\&T Clark, 2000.

de Man, Paul. Blindness \& Insight, Oxford UP, 1971.

---. Allegories of Reading: Figural Language in Rousseau, Nietzsche, Rilke, and Proust, Yale UP, 1979.

---. The Resistance to Theory, U of Minnesota P, 1986.

Derrida, Jacques. „Mythologie blanche.“ Poétique, br. 5, 1971, str. 1-52.

---. O gramatologiji. Prevela Ljerka Šifler-Premec, Veselin Masleša, 1976.

---. Pisanje i razlika. Prevela Vanda Mikšić, Naklada Šahinpašić, 2007.

Dodd, Harold Charles. The Intepretation of the Fourth Gospel, Cambridge UP, 1970.

Dumitrescu, A. Irina. „Bede’s Liberation Philology: Releasing the English Tongue.“ PMLA, sv. 128, br. 1, 2013, str. 40-56.

Fink, Eugen. Nietzscheova filozofija. Preveo Branko Despot, Centar za kulturnu djelatnost, 1981.

Grafton, Anthony. The Footnoste: A Curious History, Harvard UP, 1997.

Groth, John Henry. „Wilamowitz-Möllendorf on Nietzsche's Birth of Tragedy.“ Journal of the History of Ideas, sv. 11, br. 2, 1950, str. 179-90.

Gurd, Sean Alexander. Iphigenias at Aulis: Textual Multiplicity, Radical Philology, Cornell UP, 2005. 
Horta, Paulo Lemos. „Mixing the East with the West: Cosmopolitan Philology in Richard Burton's Translation from Camões. “ A Sea of Languages: Rethinking the Arabic Role in Medieval Liteary History, uredili Suzzane Akbari i Karla Mallete, University of Toronto, 2013, str. 82-99.

Kay, Sarah. „Post-human Philology and the Ends of Time in Medieval Bestiaries.“ Postmedieval, sv. 5, br. 4, 2014, str. 473-85.

Kermode, Frank. „John.“ The Literary Guide to the Bible, uredili Robert Alter i Frank Kermode, Harvard UP, 1987, str. 440-66.

Knapp, Peggy. „Recycling Philology.“ ADE Bulletin, br. 106, 1993, str. 13-16.

Mansfeld, Jaap. „The Wilamowitz-Nietzsche Struggle: Another New Document and Some Further Comments.“ Nietzsche-Studien, sv. 15, br. 1, 1986, str. 41-58.

McGann, Jerome. „Philology in a New Key.“ Critical Inquiry, sv. 39, br. 2, 2013, str. 327-46.

Naithani, Sadhana. „A Wild Philology.“ Marvels and Tales, sv. 28, br. 1, 2014, str. 38-53.

Nemetz, Anthony. „Literalness and the Sensus Litteralis.“ Speculum, sv. 34, br. 1, 1959, str. 76-89.

Nichols, Stephen. „Introduction: Philology as a Manuscript Culture.“ Speculum, sv. 65, br. 1, 1990, str. 1-10.

Nietzsche, Friedrich. Also sprach Zarathustra (Bd.2), Schmeintzer, 1883.

---. „Homer und die klassische Philologie.“ Frühe Schriften 5, herausgegeben von Carl Koch und Karl Schlechta, Beck, 1994 [1869], str. 283-305.

---. „Wir Philologen“. Sämtliche Werke: Kritische Studienausgabe in 15 Bänden, herausgegeben von Giorgio Collia und Mazzino Montinari, Berlin, 1980.

---. Rođenje tragedije. Prevela Vera Čičin-Šain, Matica hrvatska, 1997.

---. O istini i laži u izvanmoralnom smislu. Preveo Damir Barbarić, Matica hrvatska 1999.

Orlemanski, Julie. „Philology and the Turn Away from the Linguistic Turn. “ Florilegium, sv. 32, 2015, str. 157-81.

Patterson, Lee. „The Return to Philology.“ The Past and Future of Medieval Studies, uredio John Van Engen, U of Notre Dame P, 1994, str. 231-44.

Paulson, William. „For a Cosmoplitical Philology: Lessons from Science Studies.“ SubStance, sv. 30, br. 3, 2001, str. 101-19.

Pollock, Sheldon. „Future Philology? The Fate of a Soft Science in a Hard World. “ Critical Inquiry, sv. 35, br. 4, 2009, str. 931-61.

Pollock, Shelodon, et al., editor, World Philology, Harvard UP, 2015.

Porter, James. „'Don't Quoet Me on That!': Wilamowitz Contra Nietzsche in 1872 and 1873.“ Journal of Nietzsche Studies, sv. 42, 2011, str. 73-99.

Porter, James. „Nietzsche’s Radical Philology.“ Nietzsche as a Scholar fo Antiquity, urediliAnthony Jensen i Helmut Heit, Bloomsbury, 2014, str. 27-50.

Ricoeur, Paul. Živa metafora. Prevela Nada Vajs, Grafički zavod Hrvatske, 1981. 
Robins, William. „Toward a Disjunctive Philology.“ The Book Unbound: Editing and Reading Medieval Manuscripts and Texts, uredili Sthepen Echard i Sean Partridge, U of Toronto P, 2004, str. 144-58.

Rohde, Erwin. „Afterphilologie: Zur Beleuchtung des von dem Dr. phil. Ulrich von Wilamowitz-Möllendorff herausgegebenen Pmphlets: 'Zukunftsphilologie!' Sendschreiben eines Philologen an R. Wagner.“ Der Streit um Nietzsches „Geburt der Tragödie“: die Schriften von E. Rohde, R. Wagner, U. v. Vilamowitz-Möllendorff, herausgegeben von Krlfried Gründer, Georg Olms, 1969, str. 65-111.

Rosso, Stefano. „An Interview with Paul de Man.“ Critical Inqury, sv. 12, br. 4, 1986, str. 788-95.

Said, Edward W. 2004. „The Return to Philology." Said, Edward W. Humanism and Democratic Criticism, Columbia UP, 2004, str. 57-84.

Speigel, Gabrielle. „Reflections on The New Philology." Rethinking the New Medievalism, uredili Howard Bloch, et al., Johns Hopkins University Press, 2014, str. 39-50.

Vadde, Aarthi. „The Re-Return to Philology.“ Novel, sv. 45, br. 3, 2012, str. 461-65.

von Reibnitz, Barbara. Ein Komentare zu Friedrich Nietzsche „Die Geburt der Tragödie aus dem Geiste der Musik“, Metzler, 1992.

Warren, Michelle. „Post-Philology.“ Postcolonial Moves: Medieval Through Modern, edited by Patricia Ingham and Michelle Warren, Palgrave Macmillan, 2003, str. 19-45.

---. „Introduction: Relating Philology, Practicing Humanism.“ PMLA, sv. 125, br. 2, 2010, str. 283-88.

---. „Shimmering Philology.“ Postmdeieval, sv. 5, br. 4, 2014, str. 389-97.

Wilamowitz-MöLlendorff, Urlich von. Zukunftsphilologie! Eine Erwiderung auf Friedrich Nietzsches, Ord. Professors der class, Gebrüder Borntraeger, 1872.

--. Zukunftsphilologie! Eine Erwiderung auf Friedrich Nietzsches. Gebrüder Borntraeger, 1873.

---. Erinnerungen 1848-1914., K. F. Koehler, 1928.

Yager, Susan. „New Philology.“ Handbook of Medieval Studies. Terms - Methods - Trends, edited by Albrecht Classen, sv. 2, Walter de Gruyter, 2010, str. 999-1006.

Ziolkowski, Jan. „What is Philology.“ On Philology, uredio Jan Ziolkowski, The Pennsylvania State UP, 1990, str. 1-12.

---. „Metaphilology.“ Journal of English and Germanic Philology, sv. 104, br. 2, 2005, str. 239-72. 


\section{A NOTE ON PHILOLOGY}

\begin{tabular}{c} 
Abstract \\
Krešimir ŠıMIĆ \\
\hline Josip Juraj Strossmayer University of Osijek \\
Faculty of Humanities and Social Sciences \\
Lorenza Jägera 9 \\
HR - 31 000 Osijek \\
ksimic@ffos.hr
\end{tabular}

The article analyzes the controversy between Ulrich von Wilamowitz-Möllendorff and Friedrich Nietzsche, which began after the publication of Nietzsche's first book Die Geburt der Tragödie aus dem Geiste der Musik (1872), followed by the controversy between Walter Jackson Bate and Paul de Man on the occasion of the publication of Bate's article The Crisis in English Studies (Harvard Magazine 85, 1982). With the help of the two polemics, the author outlines the basic guidelines in the nineteenth-century and twentieth-century understanding of philology. Finally, the article brings the author's own view of philology from the point of view of Christian tradition, that is, the evangelical

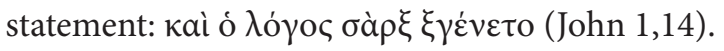

Keywords: philology, body, faith, Ulrich von Wilamowitz-Möllendorff, Friedrich Nietzsche, Walter Jackson Bate, Paul de Man 
